\title{
PENGARUH ASPEK PAJAK DAN ASPEK LAINNYA TERHADAP TINGKAT HUTANG
}

\author{
Stephanie Soerodjo \\ Sekolah Pascasarjana Fakultas Ekonomi dan Bisnis Universitas Airlangga \\ soerodjo.stephanie@protonmail.com
}

ARTICLE HISTORY

Received:

29 July 2018

Revised

17 August 2018

Accepted:

5 September 2018

Online available:

10 November 2018

Keywords (Calibri 10): leverage, corporate tax rate, non-debt tax shield, investment opportunity set, profitability, past debt, tangibility of fixed assets, Firm size, cost of financial distress

\begin{abstract}
As a developing country, Indonesia shows a quite interesting phenomenon, which is the high rate of debt of many companies in Indonesia. This fact shows that the policy of leverage plays an important role for the viability of the company.

The main purpose of this research was to test empirically factors influencing leverage, for there are still inconsistencies in research results from the prior studies. Based on the data of the mining companies listed on BEI for period 2009-2011, in addition of using tax factors that consisted of Corporate tax rate and Non-debt tax shield, influencing the leverage, there are also another factors influencing leverage, which are Investment opportunity set, Profitability, Past debt, Tangibility of fixed assets, Firm size, and Cost of financial distress.

The analyzed data are the combination of time series and cross-section data or, panel data, utilizing the regression model supported by the software SPSS 20 on 0,05 or $5 \%$ of significance level.

The result of the study shows that at the significance level of 0,05 Corporate Tax Rate (0,543), Non-debt Tax Shield (0,518), Investment Opportunity Set $(0,442)$, Tangibility of Fixed Assets (0,544), Firm Size $(0,500)$, and Cost of Financial Distress $(0,380)$ have no significant effect for the leverage. While Profitability $(0,028)$ negatively has significance effect for the leverage at the significance of 0,05 . While Past Debt $(0,000)$ has significant positive effect on the leverage at the significance of 0,05.
\end{abstract}




\section{LATAR BELAKANG}

Salah satu sumber modal perusahaan adalah hutang, baik hutang bank, maupun hutang lainnya seperti hutang obligasi. Kebijakan struktur modal perusahaan yang mencakup perimbangan antara hutang, saham preferen dan saham biasa, mempunyai peran penting bagi kelangsungan hidup perusahaan dalam jangka panjang (Saidi, 2004). Keunikan mengenai struktur modal di Indonesia sebagai negara yang sedang berkembang yaitu adanya tingkat hutang yang tinggi dalam komposisi finansial perusahaan-perusahaan di Indonesia, di mana sumber dana di Indonesia mayoritas menggunakan hutang dibanding dengan sumber dana lainnya.

Tingginya tingkat hutang pada perusahaan-perusahaan di Indonesia merupakan suatu fenomena keuangan yang cukup menarik untuk dilakukan penelitian, terutama mengenai faktor-faktor yang terkait di dalamnya. Menurut Brigham dan Houston (2001), faktor-faktor yang berpengaruh terhadap keputusan struktur modal secara umum terdiri dari faktor stabilitas penjualan, struktur aktiva, tingkat pertumbuhan, profitabilitas, pajak, pengendalian, sikap manajemen, sikap pemberi pinjaman, kondisi pasar, kondisi internal perusahaan, resiko bisnis, dan fleksibilitas keuangan.

Dalam peraturan pajak penghasilan (PPh) di Indonesia terdapat perbedaan perlakuan yang cukup signifikan antara bunga pinjaman dan pengurangan dividen sesuai dengan Pasal 6 ayat (1) huruf a Undang-undang Nomor 7 tahun 1983 sebagaimana diubah terakhir dengan Undang-undang Nomor 36 tahun 2008 (UU PPh), yang menyatakan bahwa bunga pinjaman dapat dikurangkan sebagai biaya (tax deductible) sedangkan sesuai Pasal 9 ayat (1) huruf a UU PPh dinyatakan bahwa pengeluaran dividen tidak dapat dikurangkan sebagai biaya (non tax deductible). Pengurangan biaya tersebut sangat berarti bagi perusahaan yang terkena pajak, sehingga secara otomatis akan mendorong perusahaan untuk menghitung pajaknya secara efisien yaitu dengan memanfaatkan tax deductible tersebut (Tirsono, 2008). Sebagai implikasinya, peningkatan tarif pajak akan meningkatkan penggunaan hutang perusahaan.

Selanjutnya Choi (2003) menyatakan bahwa perusahaan yang dikenakan tarif pajak marjinal yang tinggi akan memiliki insentif lebih banyak untuk mengajukan hutang karena akan mendapatkan keuntungan dari pembebanan bunga atas hutang itu. Hasil ini mempertegas adanya hubungan positif antara corporate tax rate dengan hutang.

Keuntungan pajak seperti yang diuraikan di atas adalah keuntungan pajak karena adanya pembayaran bunga hutang (debt tax shield). Di samping itu, perusahaan juga dapat memperoleh keuntungan pajak selain karena hutang yaitu yang disebut dengan non-debt tax shield. Non-debt tax shield bisa disebabkan oleh adanya fasilitas dari pemerintah yang berupa investment tax credit dan tax loss carryforward (Mackie-Mason, 1990), dan bisa dalam bentuk depresiasi aktiva tetap (Bradley et al, 1984). Investment 
tax credit adalah fasilitas yang diberikan oleh pemerintah di Indonesia pada umumnya untuk Penanaman Modal Asing (PMA) dan Penanaman Modal Dalam Negeri (PMDN) untuk menunda pembayaran pajaknya. Sedangkan tax loss carryforward adalah kerugian yang dapat dikompensasikan ke laba tahun berikutnya selama 5 tahun ke depan sehingga perusahaan dapat menunda pembayaran pajak atas laba yang telah dikompensasikan tersebut selama lima tahun ke depan (Tirsono, 2008). Terkait dengan ini, Mackie-Mason (1990) dan Mutamimah (2003) menemukan hubungan negatif antara keputusan tingkat hutang dan non-debt tax shield. Sementara Titman dan Wessels (1998) tidak berhasil menemukan hubungan yang signifikan antara hutang dengan nondebt tax shield.

Pertumbuhan perusahaan (growth) menunjukkan investment opportunity set (IOS) atau kesempatan investasi di masa yang akan datang (Jogiyanto, 2002). Peningkatan pertumbuhan suatu perusahaan akan mencerminkan adanya peningkatan peluang investasi yang cenderung untuk melakukan hutang. Penambahan hutang untuk keperluan investasi akan meningkatkan aktivitas perusahaan. Karena adanya penambahan aktiva tetap yang didanai dari hutang maka diharapkan akan meningkatkan penjualan yang tercermin dengan adanya pertumbuhan perusahaan. Penelitian yang dilakukan Rajan dan Zingales (1995) menemukan hubungan negatif antara tingkat hutang dengan kesempatan pertumbuhan. Sedangkan penelitian yang dilakukan Booth, Aivazian, Kunt dan Maksimovic (2001) dalam Choi (2003), dan Saidi (2004) menemukan hubungan positif pada negara-negara berkembang.

Aspek lain yang juga tidak kalah penting adalah keuntungan perusahaan atau profitability. Perusahaan dengan pertumbuhan penjualan tentunya diharapkan akan diikuti oleh peningkatan laba (profitability) sehingga laba ditahan (retained earning) juga akan meningkat. Dari laba ditahan (retained earning) apabila tidak digunakan untuk membayar dividen maka perusahaan cenderung untuk menggunakan laba ditahan tersebut sebagai penambah dana investasi dan tidak perlu menambah hutang. Hal ini sesuai dengan porsi struktur modal perusahaan yang terdiri dari opsi ekuitas, hutang, dan cadangan laba ditahan. Jika porsi laba ditahan besar maka untuk membiayai ekspansi perusahaan tidak terlalu membutuhkan sumber pendanaan dari hutang, karena laba ditahan itu cukup untuk membiayai pengeluaran investasi tersebut, begitu pula sebaliknya. Oleh karena itu, terjadinya peningkatan laba (profitability) berhubungan negatif dengan penambahan hutang, di mana hal ini sesuai dengan penelitian Titman dan Wessel (1988).

Faktor lain yang disinyalir berpengaruh terhadap tingkat hutang adalah hutang masa lalu atau past debt, di mana penggunaan variabel hutang masa lalu (t-1) dapat 
membantu menjelaskan apakah hutang masa lalu akan berpengaruh terhadap hutang sekarang (t). Gujarati (2003: 56) menjelaskan bahwa penggunaan variabel lag time (t-1) sangat membantu untuk menjelaskan aspek psikologis, institusional, dan teknis atas kajian yang dilakukan. Dalam banyak kasus di Indonesia perusahaan yang mampu dan berpengalaman mendapatkan hutang dalam jumlah besar di masa lalu adalah perusahaan yang dipercaya oleh lembaga keuangan (bank) untuk mendapatkan hutang baru, sehingga bank-bank lain juga berminat melakukan take over atas hutang yang ada dengan menambah hutang yang lebih besar (Tirsono, 2008).

Aspek lain yang berpengaruh terhadap tingkat hutang adalah tangibility of fixed assets, yaitu merupakan komposisi aktiva tetap perusahaan terhadap aktiva perusahaan. Menurut Frank dan Goyal (2003) menyatakan bahwa aktiva pada umumnya seperti persediaan, tanah, bangunan, dan peralatan dapat dijadikan sebagai penunjang hutang selama aktiva-aktiva tersebut dapat dijadikan jaminan. Semakin besar aktiva tetap perusahaan yang dapat dijaminkan oleh perusahaan maka semakin besar juga kemampuan perusahaan untuk menarik dana dari debitur. Ini disebabkan resiko hutang yang tidak terbayar akan berkurang karena perusahaan mampu menawarkan aktiva tetapnya sebagai jaminan. Oleh karena itu tangibility of fixed assets berpengaruh positif terhadap kebijakan hutang sebuah perusahaan. Demikian halnya menurut Setiawan (2002) terdapat pengaruh positif antara tangibility of fixed assets dengan hutang perusahaan. Pengaruh positif tersebut dikarenakan tangible assets mudah untuk dijadikan jaminan dan dapat mereduksi agency cost dari hutang (Rajan dan Zingales, 1995).

Firm size berpengaruh positif terhadap kebijakan hutang perusahaan. Perusahaan dengan firm size yang besar cenderung memiliki resiko yang lebih rendah, oleh karena itu perusahaan tersebut masih mempunyai kapasitas untuk menambah hutangnya agar dapat memanfaatkan keuntungan tax shield yang bisa didapatkan. Menurut Frank dan Goyal (2003) terdapat pengaruh positif antara firm size dengan tingkat hutang yang dimiliki perusahaan. Demikian halnya menurut Setiawan (2002) terdapat pengaruh positif antara firm size terhadap tingkat hutang. Pengaruh positif tersebut dikarenakan, semakin besar perusahaan maka cenderung semakin sedikit resiko default yang ditanggung (Rajan dan Zingales, 1995).

Kebijakan penggunaan hutang dalam struktur modal perusahaan juga dipengaruhi oleh cost of financial distress. Secara empirik, variabel cost of financial distress berpengaruh signifikan positif terhadap struktur modal. Cost of financial distress dapat diukur dengan indikator business risk. Business risk adalah variabel indikator yang menggambarkan resiko yang diciptakan akibat tidak efisiennya operasional perusahaan, di mana terdapat kegagalan kontrol internal yang mengakibatkan kerugian yang tidak 
diperkirakan sebelumnya diukur dengan deviasi standar dari EBIT dibagi dengan total aktiva. Penelitian oleh Bradley et al. (1984), dan Choi (2003) menyimpulkan bahwa variabel cost of financial distress berpengaruh signifikan positif terhadap tingkat hutang perusahaan.

Penelitian sebelumnya yang mengkaji tentang pengaruh pajak terhadap hutang telah dilakukan oleh Choi (2003) di Korea dan peneliti lain di luar Indonesia seperti Mackie-Mason (1990) dengan hasil terdapat hubungan yang positif antara pajak dengan tingkat hutang. Sedang untuk penelitian di Indonesia baru dilakukan oleh Tirsono (2008) yang mengkaji mengenai adanya hubungan yang signifikan antara pajak dengan tingkat hutang di Indonesia, di mana penelitian ini dilakukan terhadap perusahaan manufaktur yang terdaftar di BEJ setelah krisis moneter yaitu dari tahun 2001 sampai dengan tahun 2004. Pada penelitian ini, rujukan mengarah ke penelitian Tirsono (2008), dikarenakan pada penelitian terkait hasil penelitian mayoritas menunjukkan hasil yang signifikan bagi masing-masing faktor, selain didukung oleh data observasi yang kuat.

Perbedaan penelitian ini dengan penelitian sebelumnya terletak pada tahun pengamatan yang berbeda, yaitu tahun 2009 hingga 2011, sehingga sesuai dengan pemberlakuan tarif proporsional yang sekarang berlaku bagi Wajib Pajak Badan, yaitu tarif proporsional $28 \%$ pada tahun 2009, dan tarif proporsional $25 \%$ pada tahun 2010 dan 2011; sedang penelitian sebelumnya dilakukan masih pada saat pemberlakuan tarif pajak progresif. Alasan pemilihan tahun 2009 hingga 2011 sebagai periode penelitian dikarenakan peneliti terfokus pada pemberlakuan tarif pajak proporsional, di mana periode tahun 2008 dan sebelumnya masih berlaku tarif pajak progresif sedang periode tahun 2012 masih berjalan.

\section{TINJAUAN PUSTAKA}

Penelitian ini berangkat dari teori struktur modal dan tingkat hutang yang didefinisikan sebagai perbandingan antara nilai buku seluruh hutang (total debt) dengan total aktiva (total assets) oleh Weston dan Copeland (1997). Rasio ini menekankan pentingnya pendanaan hutang dengan jalan menunjukkan persentase aktiva perusahaan yang didukung dengan hutang (Darsono dan Ashari, 2005). Dengan demikian, semakin tinggi rasio ini maka semakin besar resiko yang dihadapi, investor akan meminta tingkat keuntungan yang semakin tinggi.

Menurut Manurung (2006) bahwa teori struktur keuangan atau struktur modal (structure capital) mempunyai tujuan akhir yaitu pada nilai perusahaan. Struktur keuangan perusahaan mempunyai pengaruh yang cukup besar terhadap nilai perusahaan contohnya harga saham yang diperdagangkan di bursa saham merupakan refleksi dari struktur keuangan tersebut. Para investor atau pengambil keputusan 
seringkali memperhatikan struktur keuangan perusahaan dalam rangka melakukan investasi. Teori struktur keuangan atau struktur modal yang dikaitkan dengan nilai perusahaan pertama kali dikembangkan oleh David Duran pada tahun 1952 dalam Manurung (2006) bahwa nilai perusahaan dikembangkan dengan tiga pendekatan. Salah satunya adalah pendekatan tradisional yang dinyatakan bahwa perusahaan mempunyai struktur modal yang optimal ketika nilai perusahaan maksimum. Nilai perusahaan yang maksimum berkaitan dengan biaya rata-rata modal yang minimum. Sedangkan menurut Weston dan Copeland (1997: 48), perusahaan yang menggunakan hutang telah menaikkan nilai perusahaan. Dan pengaruh atas pajak penghasilan perseroan atas hutang juga telah meningkatkan nilai perusahaan dan menurunkan biaya modal tertimbang (weighted cost of capital).

Dalam keputusan untuk menambah dana dari luar perusahaan, perusahaan dihadapkan pada pertimbangan biaya modal yang akan menjadi beban operasional usahanya, perusahaan menghendaki adanya biaya modal yang efisien atau biaya modal yang rendah. Weston dan Copeland (1997: 48) menegaskan bahwa perusahaan yang menggunakan hutang akan menurunkan biaya modal tertimbang (weighted cost of capital). Penurunan biaya modal tertimbang tersebut dipengaruhi oleh pajak penghasilan perseroan atas hutang, karena adanya biaya bunga hutang sehingga rumus weighted cost of capital adalah $\mathrm{k}=\mathrm{ku}(1-\mathrm{TL})$.

Peraturan PPh di Indonesia membedakan perlakuan biaya bunga pinjaman dengan pengeluaran dividen, bahwa bunga pinjaman dapat dikurangkan sebagai biaya (tax deductible) sesuai Pasal 6 ayat (1) huruf a UU PPh sedangkan pengeluaran dividen tidak dapat dikurangkan sebagai biaya (non-tax deductible) sesuai Pasal 9 ayat (1) huruf a UU PPh. Pengurangan biaya bunga tersebut sangat bernilai bagi perusahaan, dengan keuntungan yang diperoleh perusahaan dari penggunaan hutang tersebut disebut debt tax shield.

Adanya perbedaan pandangan yang sangat besar terhadap perlakuan menurut perpajakan bahwa bunga dapat dikurangkan sebagai biaya, sedangkan dividen tidak dapat dikurangkan sebagai biaya akan memberikan perlakuan kebijakan struktur modal perusahaan yang berbeda. Perusahaan dapat memilih dalam pembiayaan/pendanaan untuk investasinya atau aktivitasnya apakah akan memakai dana internal yang berasal dari laba ditahan (retained earning) atau melakukan hutang atau menambah modal pemilik dalam bentuk menerbitkan saham baru.

Adanya keuntungan atas pembayaran bunga (interest tax shield) menjadi penjelas bagi keputusan tingkat hutang yang lebih tinggi. Perusahaan akan terdorong untuk melakukan hutang apabila mempunyai tarif pajak marginal yang tinggi, karena adanya keuntungan atas pembayaran bunga sehingga pajak yang akan dibayarkan 
menjadi lebih kecil. Penerapan tarif pajak yang tinggi membawa pengaruh bagi perusahaan untuk melakukan efisiensi pembayaran pajak tahun mendatang karena kesempatan perusahaan untuk melakukan efisiensi tersebut akan terealisir dengan melakukan hutang tahun yang akan datang. Jadi tarif pajak yang tinggi tahun lalu (t-1) akan membawa berpengaruh terhadap hutang perusahaan tahun sekarang $(\mathrm{t})$, seperti ditegaskan oleh penelitian Graham, Lemmon dan Schallheim (1998) dan Choi (2003) yang menyatakan adanya hubungan positif antara corporate tax rate dengan hutang (struktur modal).

Dalam kaitannya dengan pajak, perusahaan telah memperoleh keuntungan pajak atas pembayaran bunga pinjaman (interest tax shield/debt tax shield). Di samping itu perusahaan juga dapat pula memperoleh keuntungan pajak yang lain disebut non-debt tax shield yaitu keuntungan pajak yang diperoleh perusahaan selain bunga pinjaman yang dibayarkan. Menurut Mackie-Mason (1990) non-debt tax shield dikelompokkan menjadi dua yaitu: tax loss carry forward dan investment tax credit. Tax loss carry forward dapat berupa kerugian yang dapat dikompensasikan ke tahun yang akan datang. Menurut UU PPh Pasal 6 Ayat (2) yang menyatakan apabila penghasilan bruto setelah pengurangan sebagaimana dimaksud dalam ayat (1) didapat kerugian, maka kerugian dapat dikompensasikan dengan penghasilan mulai tahun pajak berikutnya berturut-turut sampai dengan 5 (lima) tahun (p.123). Dari peraturan perpajakan tersebut bahwa kerugian perusahaan dapat dikompensasikan terhadap laba selama lima tahun ke depan. Karena adanya kerugian tersebut maka perusahaan dapat menunda pembayaran pajaknya lima tahun ke depan (Tax loss carry forward). Investment tax credit adalah fasilitas yang diberikan oleh pemerintah (Tirsono, 2008). Fasilitas tersebut merupakan perangsang penanaman modal yang diberikan pemerintah untuk penanaman modal dalam rangka fasilitas PMA/PMDN secara umum di Indonesia.

Menurut Bradley, Jarrel dan Kim (1984) non-debt tax shield adalah dalam bentuk depresiasi aktiva tetap. Dalam Pasal 6 ayat (1) huruf b UU PPh: Besarnya Penghasilan Kena Pajak bagi Wajib Pajak dalam negeri dan bentuk usaha tetap, ditentukan berdasarkan penghasilan bruto dikurangi: b. penyusutan atas pengeluaran untuk memperoleh harta berwujud dan amortisasi atas pengeluaran untuk memperoleh hak dan atas biaya lainnya yang mempunyai masa manfaat lebih dari satu tahun .... (p.122).

Oleh karena itu perusahaan yang mempunyai jumlah aktiva tetap yang tinggi akan semakin banyak memperoleh keuntungan pajak yaitu berupa biaya depresiasi/penyusutan yang dapat dikurangkan dalam menghitung besarnya pajak terhutang. Keuntungan pajak yang berupa biaya depresiasi/penyusutan yang dapat dikurangkan dalam menentukan penghasilan kena pajak disebut juga dengan non-debt tax shield. 
Dalam penelitian ini, pembahasan terkait non-debt tax shield akan lebih difokuskan dalam bentuk depresiasi aktiva tetap, dikarenakan tidak diberlakukannya fasilitas pengurangan pajak oleh pemerintah bagi usaha pertambangan, sebagaimana diuraikan dalam Undang-Undang Republik Indonesia Nomor 22 Tahun 2001 tentang Minyak dan Gas Bumi.

Faktor lain yang berpengaruh terhadap tingkat hutang adalah investment opportunity set (IOS), di mana pertumbuhan perusahaan (growth) menunjukkan investment opportunity set (IOS) atau kesempatan investasi di masa yang akan datang (Jogiyanto, 2002). Jogiyanto (2002) menggunakan rasio nilai pasar dibagi dengan nilai buku sebagai proxy dari IOS yang merupakan pengukur pertumbuhan perusahaan. Perusahaan yang bertumbuh mempunyai rasio lebih besar dari nilai satu yang berarti nilai pasarnya perusahaan tersebut lebih besar dari nilai bukunya.

Kesempatan pertumbuhan (growth opportunities) mencerminkan kesempatan investasi, perusahaan akan melakukan investasi ketika Tobin's $Q$ lebih besar dari 1 , dan perusahaan akan berhenti berinvestasi jika Tobin's $Q$ kurang dari 1 (Setiawan, 2006). Setiawan (2006) dalam penelitiannya menyatakan bahwa perusahaan-perusahaan di Indonesia mempunyai rata-rata Tobin's $Q$ lebih besar dari 1. Peningkatan pertumbuhan perusahaan tersebut mencerminkan adanya peningkatan peluang investasi yang selanjutnya perusahaan cenderung untuk melakukan hutang untuk membiayai investasinya.

Faktor lain yang juga berpengaruh, profitabilitas, adalah tingkat keuntungan bersih yang berhasil diperoleh perusahaan dalam menjalankan operasionalnya dalam suatu periode. Profitabilitas suatu perusahaan mencerminkan tingkat efektifitas yang dicapai oleh suatu operasional perusahaan (Ukago, 2005). Dasar pemikiran bahwa tingkat keuntungan dipakai sebagai suatu cara untuk menilai keberhasilan efektifitas perusahaan tentu saja berkaitan dengan hasil akhir dari berbagai kebijakan dan keputusan perusahaan yang telah dijalankan dalam periode berjalan. Profitabilitas dalam penelitian ini diukur dengan Return On Asset (ROA). ROA yang digunakan diukur berdasarkan model yang diusulkan oleh Weston dan Copeland (1995: 240) yaitu dengan membagi laba bersih dengan total aktiva. Pengukuran ini sesuai yang digunakan dalam penelitian dalam Ukago (2005).

Hubungan profitabilitas dengan tingkat hutang dapat dijelaskan sesuai dengan porsi struktur modal perusahaan yang terdiri dari opsi ekuitas, hutang, dan cadangan laba ditahan; jika porsi laba ditahan besar maka untuk membiayai ekspansi perusahaan tidak terlalu dibutuhkan sumber pendanaan dari hutang, karena laba ditahan itu cukup untuk membiayai pengeluaran investasi tersebut; begitu pula sebaliknya.

Published by University of Airlangga.

This is an open access article under the CC BY license (https://creativecommons.org/licenses/by-sa/4.0/) 
Penggunaan variabel hutang masa lalu (t-1) juga dapat membantu menjelaskan apakah hutang masa lalu akan berpengaruh terhadap hutang sekarang ( $\mathrm{t}$ ). Gujarati (2003: 56) menjelaskan bahwa penggunaan variabel lag time (t-1) sangat membantu untuk menjelaskan aspek psikologis, institusional, dan teknis atas kajian yang dilakukan. Penggunaan variabel lag time (t-1) yaitu hutang masa lalu akan dapat mengatasi permasalahan endogeneity dalam sudut pandang ekonometrik. Dalam banyak kasus di Indonesia perusahaan yang mampu dan berpengalaman mendapatkan hutang dalam jumlah besar di masa lalu adalah perusahaan yang dipercaya oleh lembaga keuangan (bank) untuk mendapatkan hutang baru, sehingga bank-bank lain juga berminat melakukan take over atas hutang yang ada dengan menambah hutang yang lebih besar (Tirsono, 2008).

Tangibility of fixed assets adalah komposisi aktiva tetap perusahaan terhadap aktiva perusahaan. Aktiva tetap sendiri merupakan aktiva yang digunakan untuk keperluan operasi perusahaan, bersifat jangka panjang, dan memiliki bentuk fisik (berwujud). Menurut Frank dan Goyal (2003) menyatakan bahwa aktiva pada umumnya seperti persediaan, tanah, bangunan, dan peralatan dapat dijadikan sebagai penunjang hutang selama aktiva-aktiva tersebut dapat dijadikan jaminan. Semakin besar aktiva tetap perusahaan yang dapat dijaminkan oleh perusahaan maka semakin besar juga kemampuan perusahaan untuk menarik dana dari debitur. Pendapat ini juga dipakai dalam penelitian Setiawan dan Taib (2002), yang meneliti mengenai rasio tangible of fixed assets. Semakin tinggi rasio ini menunjukkan semakin besar proporsi aktiva tetap terhadap total aktiva yang dimiliki oleh perusahaan.

Firm Size merupakan proxy dari probabilitas kebangkrutan perusahaan. Besar kecilnya firm size dapat diukur dengan beberapa cara, yaitu dapat diukur dari total aktiva yang digunakan dalam menjalankan perusahaan maupun dari total penjualan perusahaan. Dalam penelitian yang dilakukan Rajan dan Zingales (1995) mengatakan bahwa secara empiris total penjualan dapat menjelaskan tingkat hutang, hal ini disebabkan ukuran perusahaan dilihat sebagai patokan probabilitas dari kebangkrutan sehingga semakin besar perusahaan cenderung semakin sedikit resiko default yang ditanggung. Sumber pendanaan yang terdiversifikasi diakibatkan oleh kemampuan perusahaan untuk meyakinkan kepada debitur bahwa mereka ada di tingkat yang mature sehingga mampu memberi jaminan kemampuan membayar hutang tersebut.

Joni dan Lina (2010) mengatakan bahwa tolak ukur yang dapat menunjukkan besar kecilnya perusahaan adalah ukuran aktiva dari perusahaan tersebut. Perusahaan yang memiliki total aktiva besar menunjukkan bahwa perusahaan tersebut telah mencapai tahap kedewasaan di mana dalam tahap ini arus kas perusahaan sudah positif dan dianggap memiliki prospek yang baik dalam jangka waktu yang relatif lama, selain itu 
juga mencerminkan bahwa perusahaan relatif lebih stabil dan lebih mampu menghasilkan laba dibanding perusahaan dengan total asset yang kecil.

Cost of financial distress adalah variabilitas earnings dan dapat menjadi ukuran resiko bisnis suatu perusahaan, di mana kreditor cenderung memberikan pinjaman kepada perusahaan yang mempunyai earning relatif stabil. Selain itu, manajemen juga perlu memperhitungkan distress cost yang akan ditimbulkan dari hutang yang semakin tinggi. Distress cost ini berkaitan dengan biaya-biaya yang akan dikeluarkan apabila terjadi kebangkrutan (bankruptcy costs), biaya tidak langsung (indirect cost) berupa biaya yang timbul akibat kehilangan penjualan atau pendapatan, serta konflik kepentingan yang akan terjadi dimana pihak kreditor dan pemegang saham akan mengkhawatirkan pengembalian atas dana mereka (Choi, 2003).

\section{METODE PENELITIAN}

Dalam penelitian ini dianalisis pengaruh antara tarif pajak penghasilan badan dan perlindungan pajak selain hutang (Non-debt Tax Shield), serta faktor non-pajak lainnya terhadap tingkat hutang perusahaan. Kurun waktu yang akan diambil dalam penelitian ini adalah 2009 hingga 2011 (tiga tahun). Dalam periode tersebut dimungkinkan perusahaan mengalami perubahan jumlah hutang dan juga faktor-faktor yang lain yang semakin meningkat.

Panel data atau polled data adalah metode ekonometrik yang menganalisis data time series dan cross-section secara bersamaan (Gujarati, 2003). Analisis ini memberikan banyak keuntungan, antara lain panel data dapat mengatasi masalah heterogenitas perusahaan-perusahaan yang diteliti; dengan adanya kombinasi data time series dan cross-section, panel data memberikan data yang lebih informatif, mengurangi kolineritas antar variabel, dan lebih efisien; panel data lebih mampu menganalisis perubahan dinamis pada perusahaan-perusahaan yang diteliti. Panel data menggunakan model regresi yang dikenal dengan model regresi panel data. Keseluruhan pengolahan data dalam penelitian ini menggunakan software SPSS 20.

Untuk menguji hipotesis yang dilakukan dalam penelitian ini digunakan model analisis regresi berganda stepwise. Secara parsial pengujian terhadap hipotesis pertama hingga kedelapan menggunakan uji t dengan tingkat signifikansi 0,05 atau 5\%. Model regresi tersebut akan menghasilkan $\mathrm{R}^{2}$ yang menyatakan keeratan hubungan antar dua variabel yang akan diuji. Hipotesis yang diuji dengan melihat nilai $t$ hitung dan $t$ tabel atau $\mathrm{p}$ value dengan ketentuan sebagai berikut: Hipotesis alternatif $(\mathrm{Ha})$ diterima jika; $\mathrm{t}$ hitung $>\mathrm{t}$ tabel atau $\mathrm{p}$ value $<0,05$.

Published by University of Airlangga.

This is an open access article under the CC BY license (https://creativecommons.org/licenses/by-sa/4.0/) 
Data penelitian ini menggunakan perusahaan-perusahaan pertambangan yang terdaftar di Bursa Efek Indonesia. Berdasarkan data yang telah dikumpulkan terdapat 26 perusahaan pertambangan yang terdaftar di Bursa Efek Indonesia, namun hanya 21 perusahaan yang digunakan dalam penelitian ini selama 3 tahun atau jumlah observasi seluruhnya adalah 63, yaitu terdiri dari 10 perusahaan pertambangan batu bara, 5 perusahaan pertambangan minyak dan gas bumi, 4 perusahaan pertambangan logam dan mineral lainnya, 2 perusahaan pertambangan batu-batuan, dan selebihnya tidak memenuhi syarat.

\section{HASIL PENELITIAN DAN ANALISA}

Berdasarkan hasil analisis yang disajikan dalam Tabel 2. Hasil uji model 2 (Model Summary 2) menunjukkan besarnya nilai koefisien determinasi $\left(R^{2}\right)$ adalah 0,442 , yang berarti bahwa variabel-variabel independen dapat memberikan sebagian besar informasi yang dibutuhkan variabel dependen.

Table 1 (Center, Calibri 10)

Consumption on Ramadhan (Center, Calibri 10)

\begin{tabular}{|l|l|l|l|}
\hline Model & $R$ & R Square & Adjusted R Square \\
\hline 1 & $.628^{\mathrm{a}}$ & .395 & .385 \\
2 & $.665^{\mathrm{b}}$ & .442 & .423 \\
\hline
\end{tabular}

a. Predictors: (Constant), Past Debt

b. Predictors: (Constant), Past Debt, Profitability

Namun karena penelitian ini menggunakan beberapa variabel penelitian, maka akan lebih baik jika determinasi menggunakan Adjusted $R^{2}$. Besarnya Adjusted $R^{2}$ menurut Tabel Model Summary 2 adalah 0,423 atau sebesar 42\% variasi leverage dalam hubungannya dengan variabel-variabel independen dapat dijelaskan oleh variabel Past Debt dan Profitability dalam model ini, sedangkan selebihnya hampir 58\% dijelaskan oleh variabel lainnya yang tidak diteliti dalam penelitian ini.

Hasil penelitian menunjukkan bahwa t hitung dari Corporate Tax Rate adalah 0,612 dengan nilai signifikansi 0,543 atau > dari 0,05 karena nilai signifikansi atau probabilitas pengujian > 0,05 sehingga hipotesis 1 ditolak. Hipotesis 1 ditolak berarti secara empiris tidak terbukti bahwa Corporate Tax Rate berpengaruh secara signifikan positif terhadap tingkat hutang pada tingkat signifikansi 0,05 atau $5 \%$. Hasil penelitian ini 
tidak sesuai dengan penelitian yang dilakukan oleh Choi (2003) yang menyatakan adanya hubungan positif antara corporate tax rate dengan tingkat hutang

Hasil penelitian juga menunjukkan bahwa t hitung dari Non-debt Tax Shield adalah -0,650 dengan nilai signifikansi 0,518 atau > dari 0,05 karena nilai signifikansi atau probabilitas pengujian $>0,05$ maka hipotesis 2 ditolak. Hipotesis 2 ditolak berarti terbukti secara empiris bahwa Non-debt Tax Shield tidak berpengaruh signifikan terhadap tingkat hutang. Hasil penelitian ini mendukung hasil penelitian yang dilakukan oleh Titman dan Wessels (1988) dalam penelitiannya tidak berhasil menemukan hubungan yang signifikan antara Non-debt Tax Shield dengan tingkat hutang.

Hasil penelitian menunjukkan bahwa t hitung dari Investment Opportunity Set adalah 0,774 dengan nilai signifikansi 0,442 atau > dari 0,05 karena nilai signifikansi atau probabilitas pengujian $>0,05$ maka hipotesis 3 ditolak. Hipotesis 3 ditolak berarti terbukti empiris bahwa Investment Opportunity Set tidak berpengaruh signifikan terhadap tingkat hutang. Hasil penelitian ini menemukan adanya pengaruh yang positif, walaupun tidak signifikan, antara kesempatan pertumbuhan dengan tingkat hutang, maka dapat disimpulkan bahwa pada saat perusahaan mengalami pertumbuhan, perusahaan memerlukan dana yang cukup besar sehingga perusahaan cenderung untuk melakukan hutang daripada menggunakan dana internal sendiri (retained earning) hal ini sesuai dengan Trade-off Theory.

Hasil penelitian menunjukkan bahwa t hitung dari Profitability adalah -2,257 dengan nilai signifikansi 0,028 atau < dari 0,05 karena nilai signifikansi atau probabilitas pengujian < 0,05 maka hipotesis 4 diterima. Hipotesis 4 diterima berarti terbukti secara empiris bahwa Profitability berpengaruh signifikan negatif terhadap tingkat hutang, dan hasil penelitian ini mendukung hasil penelitian Titman dan Wessels (1988), dan Rajan dan Zingales (1995), Tirsono (2008) yang menyatakan Profitability berpengaruh secara signifikan negatif terhadap tingkat hutang. Hasil penelitian ini mendukung pecking-order theory yang mengemukakan bahwa perusahaan cenderung menggunakan dana internal terlebih dulu, baru kemudian menggunakan dana eskternal.

Hasil penelitian membuktikan bahwa t hitung dari Past Debt adalah 5,358 dengan nilai signifikansi 0,000 atau < dari 0,05 maka hipotesis 5 dapat diterima. Hipotesis 5 diterima secara empiris terbukti bahwa terdapat hubungan yang signifikan positif antara tingkat hutang masa lalu dengan tingkat hutang masa sekarang. Hasil penelitian ini mendukung hasil penelitian yang telah yang dilakukan oleh Tirsono (2008) yang membuktikan terdapat hubungan yang signifikan positif antara tingkat hutang masa lalu dengan tingkat hutang masa sekarang.

Hasil penelitian menunjukkan bahwa $t$ hitung dari Tangibility of Fixed Assets adalah 0,611 dengan nilai signifikansi 0,544 atau > dari 0,05 karena nilai signifikansi atau 
probabilitas pengujian > 0,05 maka hipotesis 6 ditolak. Hipotesis 6 ditolak berarti terbukti secara empiris bahwa Tangibility of Fixed Assets tidak berpengaruh signifikan terhadap tingkat hutang. Hasil penelitian ini sejalan dengan penelitian yang dilakukan oleh Hidayati (2010) yang menyatakan tidak berpengaruhnya variabel aktiva tetap terhadap struktur modal.

Hasil penelitian membuktikan bahwa t hitung dari Firm Size adalah 0,678 dengan nilai signifikansi 0,500 atau > dari 0,05 maka hipotesis 7 ditolak. Hipotesis 7 ditolak berarti terbukti secara empiris bahwa Firm Size tidak berpengaruh signifikan terhadap tingkat hutang. Hasil penelitian ini sejalan dengan penelitian yang dilakukan oleh Hidayati (2010) yang menyatakan tidak terdapat pengaruh ukuran perusahaan terhadap struktur modal.

Hasil penelitian menunjukkan bahwa $\mathrm{t}$ hitung dari Cost of Financial Distress adalah 0,885 dengan nilai signifikansi 0,380 atau > dari 0,05 karena nilai signifikansi atau probabilitas pengujian $>0,05$ maka hipotesis 8 ditolak. Hipotesis 8 ditolak berarti terbukti secara empiris bahwa Cost of Financial Distress tidak berpengaruh signifikan terhadap tingkat hutang. Hasil penelitian ini sejalan dengan penelitian yang dilakukan oleh Saidi (2004) yang menyatakan resiko kebangkrutan tidak berpengaruh terhadap struktur modal.

\section{KESIMPULAN}

Berdasarkan uji hipotesis di atas maka:

1. Corporate Tax Rate tidak berpengaruh secara signifikan terhadap tingkat hutang pada tingkat signifikansi 0,05 atau 5\%, sehingga tidak mendukung hipotesis 1 . Hal ini mengindikasikan besar kecilnya pajak yang harus dibayar tahun lalu tidak berpengaruh signifikan terhadap tingkat hutang perusahaan, sejak diberlakukanya tarif pajak proporsional penghasilan.

2. Non-debt Tax Shield tidak berpengaruh secara signifikan terhadap tingkat hutang pada tingkat signifikansi 0,05 atau 5\% sehingga tidak mendukung hipotesis 2 . Hasil ini juga menunjukkan bahwa depresiasi tidak mempengaruhi hutang yang artinya bahwa hutang tersebut tidak digunakan untuk mendanai investasi dalam bentuk aktiva tetap, akan tetapi hutang tersebut digunakan oleh perusahaan untuk mendanai operasional perusahaan sebagai modal kerja.

3. Investment Opportunity Set tidak berpengaruh secara signifikan terhadap tingkat hutang pada tingkat signifikansi 0,05 atau 5\%, sehingga tidak mendukung hipotesis 3. Hasil penelitian ini menemukan adanya pengaruh yang positif, walaupun tidak signifikan, antara kesempatan pertumbuhan dengan tingkat hutang, maka dapat disimpulkan bahwa pada saat perusahaan mengalami pertumbuhan, perusahaan memerlukan dana yang cukup besar sehingga 
perusahaan cenderung untuk melakukan hutang daripada menggunakan dana internal sendiri (retained earning) hal ini sesuai dengan Trade-off Theory. Terkait dengan tidak signifikannya pengaruh positif ini, bisa diakibatkan dari kurangnya sampel penelitian yang terdiri dari 21 perusahaan pertambangan saja.

4. Profitability berpengaruh secara signifikan negatif terhadap tingkat hutang pada tingkat signifikansi 0,05 atau $5 \%$ sehingga mendukung hipotesis 4 . Hal ini mengindikasikan bahwa sesuai dengan pecking-order theory, perusahaan cenderung menggunakan dana internal terlebih dulu, baru kemudian menggunakan dana eskternal. Perusahaan yang sangat menguntungkan (profitable) pada dasarnya tidak membutuhkan banyak pembiayaan dengan hutang, karena laba yang ditahan perusahaan yang tinggi sudah memenuhi untuk membiayai sebagian besar kebutuhan pendanaan.

5. Past Debt berpengaruh secara signifikan positif terhadap tingkat hutang pada tingkat signifikansi 0,05 atau $5 \%$, sehingga mendukung hipotesis 5 . Hal ini mencerminkan bahwa perusahaan-perusahaan di Indonesia, termasuk perusahaan pertambangan, yang mampu dan berpengalaman mendapatkan hutang dalam jumlah besar di masa lalu adalah perusahaan yang dipercaya oleh lembaga keuangan (bank) untuk mendapatkan hutang baru.

6. Tangibility of Fixed Assets tidak berpengaruh secara signifikan terhadap tingkat hutang pada tingkat signifikansi 0,05 atau $5 \%$ sehingga tidak mendukung hipotesis 6. Hal ini mengindikasikan bahwa dalam kasus perusahaan pertambangan, aset tetap bukan menjadi aset yang utama dalam perusahaan, di mana proporsi aset tetap hanya sebesar $29 \%$ dari total aset, sedangkan secara rata-rata tingkat hutangnya mencapai 53\%. Dari fakta ini dapat disimpulkan bahwa dalam kasus perusahaan pertambangan, kreditur tidak berpegang pada jumlah aktiva tetap perusahaan dalam pemberian hutang kepada debitur; kreditur melihat aspek-aspek lain dalam kebijakannya, misalnya kredibiltas dan nama besar perusahaan, yang dikarenakan karakteristik perusahaan pertambangan yang memiliki proporsi jumlah aktiva tetap yang rendah terhadap keseluruhan jumlah aktiva.

7. Firm Size tidak berpengaruh secara signifikan terhadap tingkat hutang pada tingkat signifikansi 0,05 atau 5\% sehingga tidak mendukung hipotesis 7 . Hal ini mengindikasikan bahwa besar kecilnya perusahaan tidak berpengaruh signifikan terhadap tingkat hutang, hal ini mungkin diakibatkan kurangnya sampel penelitian yang terdiri dari 21 perusahaan pertambangan saja, yang menyebabkan kurang signifikannya hubungan adalah firm size dengan tingkat hutang perusahaan. 
8. Cost of Financial Distress tidak berpengaruh secara signifikan terhadap tingkat hutang pada tingkat signifikansi 0,05 atau 5\% sehingga tidak mendukung hipotesis 8. Hal ini mengindikasikan bahwa dalam kasus perusahaan pertambangan di Indonesia, cost of financial distress tidak berpengaruh signifikan terhadap tingkat hutang. Justifikasinya dikarenakan dalam kenyataannya dalam memutuskan tingkat hutangnya manajer kurang memperhatikan masalah resiko kebangkrutan yang dihadapi dikarenakan terdapat faktor lain yang lebih berpengaruh. Hal ini dimungkinkan karena dalam periode 2009-2011 perusahaan sektor pertambangan belum mengalami kondisi lingkungan bisnis yang pasti, sebagai dampak dari ketidakteraturan sektor perekonomian Indonesia.

\section{DAFTAR REFERENSI}

Bradley M., Jarrel G. A., and Kim E.H. 1984. "On The Existence of An Optimal Capital Strukture: Theory and Evidence". Journal of Finance 39. pp. 857-878.

Brigham, Eugene F. dan Joel F. Houston. 2001. Manajemen Keuangan, Edisi 8, Erlangga, Jakarta.

Chung, Kee H., and Stephen W. Pruit. 1994. "A Simple Approximation of Tobin's q", Journal of Financial Management Vol.3 No.3. pp.70-74.

Choi, Young Rok. 2003. "Taxes and Corporate Capital Strukture" Proposal Economics 413. P. Mueser.

Daniati, Ninna dan Suhairi. 2006. Pengaruh Kandungan Informasi Komponen Arus Kas, Laba Kotor dan Size Perusahaan Terhadap Expected Return Saham Pada Industri Textile dan Automotive yang Terdaftar di BEJ, Simposium Nasional Akuntansi 9 Padang, Agustus.

Darsono dan Ashari. 2005. Pedoman Praktis Memahami Laporan Keuangan, Andi Offset, Yogyakarta.

Frank, Murray Z and Goyal, Vidhan K. 2003. Capital Structure Decisions. Journal of Economic Financial, Published by Elsevier Science. Vol.0304-405X/02.

Gujarati D. 2003. Basic Econometric, Fourth edition, Mc Graw-Hill Inc.

Hakim, Moch. Luqman. 2008. "Analisis beberapa variabel yang memengaruhi struktur modal perusahaan sektor pertambangan di bursa efek Indonesia." Program Pasca Sarjana Universitas Pembangunan Nasional Veteran Jawa Timur.

Hidayati, Nuril. 2010. "Pengaruh Struktur Kepemilikan, Profitabilitas, Ukuran Perusahaan, Aktiva Tetap, dan Risiko Bisnis Terhadap Struktur Modal Pada Perusahaan yang masuk Dalam Kelompok Jakarta Islamic Indeks Masa tahun 2005-2007.".

Homaifar, Zeitz and Benkato. 1994. "An Empirical Model of Capital Structure; Some New Evidence", Journal of Business Finance \& Accounting, Vol.21 No.1, Januari 1994.

Imam Ghozali. 2007. Aplikasi Analisis Multivariate dengan Program SPSS, Penerbit Universitas Diponegoro, Semarang.

John R. Graham, Michael L. Lemmon and James S, Schallheim. 1998. "Debt, Leases, Taxes and the Endogeneity of Corporate Tax Status". Journal of Finance 53, 131-162. 
Jogiyanto. 2002. Teori Portofolio Pasar Modal, Penerbit BPFE -UGM Yogyakarta.

Joni dan Lina. 2010. "Faktor-faktor yang Mempengaruhi Struktur Modal." STIE Trisakti. Jurnal Bisnis dan Akuntansi Vol. 12, No. 2, Agustus 2010, HIm. 81-96.

Keputusan Menteri Keuangan Nomor 1002/KMK.04/1984 tentang Penentuan Perbandingan antara Utang dan Modal Sendiri untuk Keperluan Pengenaan PPh.

Kiswara, Endang. 2006. Strategi Perencanaan Pajak Edisi Pertama, Badan Penerbit UNDIP.

Kusmana, Eunice dan Stephany Luchiana. 2006. "Analisis pengaruh tangibility of asset, profitability, growth opportunity, firm size dan financial deficit terhadap tingkat hutang: studi pada perusahaan farmasi yang go public di bursa efek Jakarta." Program Studi Sarjana Ekonomi Universitas Kristen Petra.

MacKie - Mason, Jeffrey K.. 1990. “Do Taxes Affect Corporate Financing Decisions?”, The Journal of Finance Vol. XLV No.5, Dec. 1990.

Manurung, Adler. 2006. Cara Menilai Perusahaan Cetakan Pertama PT. Elex Media Komputindo Jakarta.

Mas'ud, Masdar. 2008."Analisis Faktor-Faktor yang Mempengaruhi Struktur Modal dan Hubungannya Terhadap Nilai Perusahaan". Fakultas Ekonomi Universitas Muslim Indonesia. Manajemen dan Bisnis, Volume 7, Nomor 1, Maret 2008.

Miller, Merton. 1977. "Debt and Taxes". Journal of Finance. 32-2. PP 261-275.

Modigliani, Franco and Merton Miller. 1958. "The Cost of Capital, Corporation Finance and The Theory of Investment". The American Economic Review 47-3. pp. 261297.

Mutamimah, 2003, “Analisis Struktur Modal Pada Perusahaan-perusahaan Non-Finansial Yang Go Publik di Pasar Modal Indonesia". Jurnal Bisnis Strategi Vol.11, Juli 2003.

Myers S.C. and Majluf N.S. 1984. "Corporate Financing and Investment decisions when firms have information that invertor do not have." Journal of Financial Economics, Vol.13.p.187-221.

Oliver, Barry. 2005. The determinants of capital structure for Japanese multinational and domestic corporations. Working paper School of Finance and Applied Statistics, Faculty of Economics and Commerce, Australian National University, Canberra Australia.

Pandey, I. M. 2001. "Capital Structure and The Firm Characteristics: Evidence From An Emerging Market". TIMA Working Paper.

Pandey, I. M. 2003. "Capital Strukture and Market Power Interaction: Evidence from Malaysia, in Zamri Ahmad, Ruhani Ali, Subramaniam Pillay". Proceedings for the fourth annual Malaysian Finance Association Symposium 31 May-1 June 2002. Penang. Malaysia.

Rajan, Raghuram G., and Luigi Zingales. 1995. "What Do We Know About Capital Structure? Some Evidence from International Data". Journal of Finance 5. pp. 1421-1460.

Saidi. 2004. "Faktor-faktor Yang Memengaruhi Struktur Modal Pada Perusahaan Manufaktur Yang Go Publik di BEJ Tahun 1997-2002". Jurnal Bisnis \& Ekonomi Vol.11, No.1 Maret 2004.

Published by University of Airlangga.

This is an open access article under the CC BY license (https://creativecommons.org/licenses/by-sa/4.0/) 
Setiawan, Agustinus. 2006. "Dampak Penentuan Struktur Modal terhadap Permasalahan Moral Hazard pada Perusahaan di Indonesia sebelum dan selama Krisis Ekonomi" Paper Konferensi Nasional, Prasetiya Mulya Business School. PPI-39.

Setiawan, Agustinus, Fauziah Md Taib, Suhaimi Shahnon. 2002. The determinants of corporate debt in Indonesia public listed companies. Jurnal Ekonomi dan Bisnis (Dian Ekonomi) 8 (1), 17-35.

Singgih, Santoso. 2001, SPSS Statistik Parametrik, Edisi Kelima, Penerbit PT Slerk Gramedia, Jakarta.

Shuetrim G., Lowe P., and Morling S. 1993. "The Determinants of Corporate Tingkat hutang: A panel Data Analysis". Research Discussion Paper Reserve Bank of Australia. pp. 1-52. Journal of Finance 39.

Smith, Barclay J.M. and Cilfford W. Jr. 1995. "The Maturity Structure of Corporate Debt" The Journal of Finance Vol. L No.2.

Titman, Sheridan, and Roberto Wessels. 1988. "The Determinants of Capital Structure Choice". Journal of Finance. pp. 1-19.

Tirsono. 2008. "Analisis Faktor Pajak dan Faktor-faktor lain Yang Berpengaruh Terhadap Tingkat Utang pada Perusahaan Manufaktur yang Terdaftar di Bursa Efek Jakarta”. Program Studi Magister Sains Akuntansi Universitas Diponegoro Semarang.

Ukago, Kristianus. 2005. "Faktor-faktor yang Berpengaruh Terhadap Ketepatan Waktu Pelaporan Keuangan Bukti Empiris Emiten di BEJ". Jurnal Maksi Vol.5 Jan. 2005.

Undang-undang Republik Indonesia Nomor 28 Tahun 2007 tentang Perubahan Ketiga atas Undang-undang Nomor 6 tahun 1983 tentang Ketentuan Umum dan Tata Cara Perpajakan, Penerbit Salemba Empat - Jakarta - 2010.

Undang-undang Republik Indonesia Nomor 36 Tahun 2008 tentang Perubahan Keempat atas Undang-undang Nomor 7 tahun 1983 tentang Pajak Penghasilan, Penerbit Salemba Empat - Jakarta - 2010.

Weston, J. Fred dan Thomas E. Copeland. 1995. Manajemen Keuangan Edisi Kesembilan, Jilid I, Binarupa Aksara-Jakarta.

Weston, J. Fred dan Thomas E. Copeland. 1997. Manajemen Keuangan Edisi Kesembilan, Jilid II, Binarupa Aksara-Jakarta. 